BRIEF REPORT

\title{
Smoke-free law did not affect revenue from gaming in Delaware
}

\author{
L L Mandel, B C Alamar, S A Glantz
}

Tobacco Control 2005;14:10-12. doi: 10.1136/tc.2004.008755

Objective: To determine the effect of the Delaware smokefree law on gaming revenue.

Methods: Linear regression of gaming revenue and average revenue per machine on a public policy variable, time, while controlling for economic activity and seasonal effects.

Results: The linear regression showed that the smoke-free law was associated with no effect on total revenue or average revenue per machine.

Conclusion: Smoke-free laws are associated with no change in gaming revenue.

$\mathrm{S}$ moke-free policies reduce cigarette consumption, ${ }^{1}$ which translates into lost tobacco industry revenue. Because of its lack of public credibility, the tobacco industry has used its allies in the hospitality industry, including the gaming industry, ${ }^{2}$ to act as surrogates in the fight against smoke-free workplaces. ${ }^{3}$ Despite the claims of the tobacco industry and its allies in the hospitality industry, ${ }^{3}$ it has been shown that smoke-free ordinances have no effect or a positive effect on restaurant and bar revenues, ${ }^{4}$ bingo revenue, ${ }^{5}$ and restaurant values. ${ }^{6}$

In response, opponents of smoke-free workplaces have claimed that smoke-free laws still negatively affect gaming revenue. In 2003, the gaming industry in Delaware was continuing to blame the November 2002 Delaware Clean Indoor Air Law for reduced revenue and layoffs. ${ }^{78}$ In May 2003, a gaming executive from Park Place Entertainment, which operates gaming facilities in Delaware (Dover Downs) and New Jersey, testified against a proposed smoke-free law at a New Jersey State Senate Health Committee hearing. The executive claimed that the Delaware Clean Indoor Act had a negative effect on gaming revenue and that her concerns for New Jersey were "supported by the results that happened in Delaware". 9 The executive claimed that Dover Downs, a racino that includes video slot machines and horse racing, had experienced a $25 \%$ drop in revenue and already reduced its staff by 100 workers since the Clean Indoor Air Act. She stated that Dover Downs would continue to reduce staff by as much as double what they already had if revenue continued to decrease, a trend she claimed would continue as long as the casinos were forced to be smoke-free. The executive admitted that factors such as other economic variables and weather may have played a role in the decrease in revenue, but concluded on behalf of the Casino Association of New Jersey, that "we would expect significant pressure on a business as a result of the enactment of this [proposed New Jersey smoke-free] bill". ${ }^{\prime}$

The executive failed to mention that Park Place Entertainment's first quarter Securities and Exchange Commission (SEC) filing stated that the $7 \%$ decrease in revenue for its three casinos in Atlantic City and the management fees from Dover Downs was mainly caused by inclement weather. ${ }^{10}$ The online summary of the filing did not mention the smoking restrictions as a reason revenue was down from the first quarter of the previous year. ${ }^{10}$

In 1994, Delaware passed legislation that allowed each of the state's three racetracks to have slot machine-like video lottery terminals. Delaware Park and Dover Downs have operated machines since December, 1995 and Harrington Raceway has operated machines since August, 1996. ${ }^{11}$ As of May 2004, Delaware Park operated 2475 machines and Dover Downs operated 2500 machines, and the Harrington Raceway operated 1435 machines.

On 27 November 2002 the state of Delaware implemented the Delaware Clean Indoor Air Act, a comprehensive state wide smoke-free law that made virtually all of Delaware's public places and workplaces smoke-free, including the three racinos. ${ }^{12}$

\section{METHODS}

Regression analysis was used to test for the effects of the smoke-free law on the gaming industry in Delaware. Data on gaming revenue by establishment and number of machines per establishment from January 1996 (Delaware Park and Dover Downs) and from August 1996 (Harrington) to May 2004 (for all three facilities) were obtained from the Delaware Video Lottery. ${ }^{13}$ The revenue data were then inflated to May 2004 dollars using the Chained Consumer Price Index (CPI) published by the US Bureau of Labor Statistics. ${ }^{14}$ The revenue and machine data were used to calculate the average revenue per machine on a total basis.

Estimates of annual personal income are published quarterly for the MidEast region by the US Bureau of Economic Analysis. ${ }^{15}$ The data were interpolated to create monthly estimates. These monthly estimates of income were used as a control for economic activity. To further control for any economic or other changes not accounted for by the income, a time variable with 1996 set to 0 and increasing by one for each month was included in the regression equation. The time variable was tested for both linear and quadratic effects with the quadratic specification providing a better fit. The better fit for the quadratic time specification is likely due to the maturing, and thus slowing growth, of gaming in Delaware. Seasonal dummy variables were also tested in the models with winter defined as December, January, and February; spring defined as March, April, and May; and summer defined as June, July, and August. Only winter was found to be significant, thus only the results with winter are reported.

We tested for effects of the law on two variables: total revenues and average revenue per machine. We did this by using a dummy policy variable, $\mathrm{P}_{\text {law }}$, that was set to zero pre smoke-free law and was set to one for every month the law was in effect.

Total revenues $=\beta_{\text {law }} \mathrm{P}_{\text {law }}+\gamma_{\text {Time Time }}+\epsilon_{\text {time } 2 \text { Time }}{ }^{2}+$ $\alpha_{\text {Machines }}$ Machines $+\chi_{\text {Income }}$ Income $+\eta_{\text {Winter }}$ Winter 
Table 1 Estimated effects of the smoke-free law

\begin{tabular}{|c|c|c|c|c|c|c|}
\hline \multirow[b]{2}{*}{ Variable } & \multicolumn{3}{|c|}{ Total revenues (\$million) } & \multicolumn{3}{|c|}{$\begin{array}{l}\text { Average revenue per machine } \\
\text { (\$/machine) }\end{array}$} \\
\hline & Estimate & SE & $\mathrm{p}$ Value & Estimate & SE & p Value \\
\hline $\begin{array}{l}\text { Plaw (unit/month) } \\
\text { Time (unit/month) } \\
\text { Time }^{2} \text { (unit/month' } \\
\text { Machines (unit/machine) } \\
\text { Income (unit/\$million) } \\
\text { Winter } \\
\mathrm{n} \\
R^{2}\end{array}$ & $\begin{array}{r}4.582 \\
0.562 \\
-0.005 \\
0.004 \\
8.761 \\
-4.653 \\
101 \\
0.803\end{array}$ & $\begin{array}{l}2.968 \\
0.117 \\
0.001 \\
0.002 \\
1.734 \\
1.149\end{array}$ & $\begin{array}{l}0.126 \\
<0.001 \\
<0.001 \\
0.017 \\
<0.001 \\
<0.001\end{array}$ & $\begin{array}{c}735 \\
78.48 \\
-0.849 \\
-2.424 \\
12415 \\
-1405 \\
101 \\
0.622\end{array}$ & $\begin{array}{c}725.95 \\
35.95 \\
0.259 \\
0.445 \\
562.9 \\
315\end{array}$ & $\begin{array}{l}0.314 \\
0.032 \\
0.001 \\
<0.001 \\
<0.001 \\
<0.001\end{array}$ \\
\hline
\end{tabular}

The same specification as above was also used for average revenues per machine. The parameters were estimated using ordinary least squares.

\section{RESULTS}

The estimates from the equation are reported in table 1 and fig 1 . Both estimations show a good fit to the data with an $R^{2}$ of 0.803 for total revenues and an $R^{2}$ of 0.622 for average revenues per machine. Controlling for underlying economic conditions, the results show no significant effect of the smoke-free law for either total revenues $(p=0.126)$ or
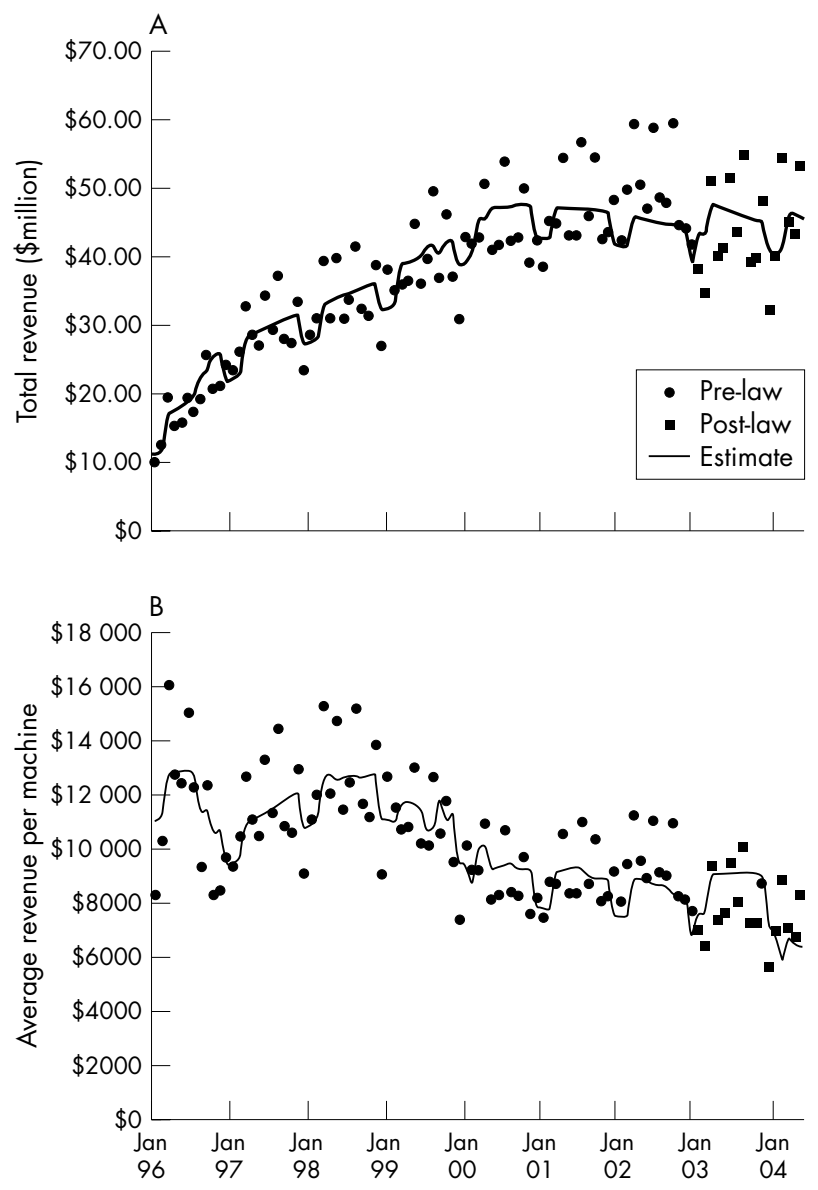

Figure 1 (A) Total revenues increase from the creation of the racinos and then flatten out with the economic downturn. No significant relation between total revenues and the smoke-free law exist. (B) Average revenues per machine vary overtime and decrease with the downturn in the economy. No significant relation between average revenues and the smoke-free law exist.

\section{What this paper adds}

Many studies have previously examined the effects of smokefree laws and ordinances on the hospitality industry and charitable bingo. These studies have found either a positive or no effect on restaurant values, revenues, and employment; bar revenues and employment; and on bingo revenues. No previous study, however, has examined the effects of a state wide smoke-free law on gaming revenue.

This study is the first to show no impact of smoke-free laws on gaming revenues. The paper tests for effects on both total revenues and average revenues per machine and finds no significant changes associated with the smoke-free law.

average revenues per machine $(p=0.314)$. These results indicate that the smoke-free law had no effect on the total revenues (power to detect a $10 \%$ drop in revenues 0.98 ) or the average revenue per machine (power to detect a $10 \%$ drop in average revenues 0.97 ).

\section{DISCUSSION}

The smoke-free law had no detectable effect on total gaming revenue or the average revenue per machine. These results reject the argument that smoke-free laws hurt revenues from gaming. No effects were found on total revenue or average revenues per machine. Smoke-free laws do not harm racinos just as they do not harm restaurants, bars, or bingo parlours. ${ }^{456}$

Outside Delaware, casinos and other gaming facilities including bars, taverns, restaurants, and grocery stores with video gaming machines remain one of the last places that continue to be exempt from smoke-free ordinances. This type of gaming venue is the fastest growing sector within the gaming industry. Frank Fahrenkopf, one of the casino industry's top Washington DC based lobbyists and president of the American Gaming Association, predicted at his keynote speech at the 2003 American Gaming Summit in Las Vegas that the continued growth of racinos, not resort style casinos, will fuel the expansion of the gaming industry. ${ }^{16}$ It is important that state legislatures and public health advocates in states considering allowing racinos know that despite the claims from opponents, smoke-free laws do not affect gaming revenue.

\section{Authors' affiliations}

L L Mandel, B C Alamar, S A Glantz, Center for Tobacco Control, Research \& Education, University of California, San Francisco, San Francisco, California, USA

This research was supported by National Cancer Institute Grant CA61021 
Correspondence to: Professor Stanton A Glantz, Center for Tobacco Control, Research \& Education, University of California, San Francisco, 530 Parnassus Ave, Suite 366, San Francisco, CA 94143, USA; glantz@medicine.ucsf.edu

Received 5 May 2004

Accepted 14 July 2004

\section{REFERENCES}

1 Fichtenberg CM, Glantz SA. Effect of smoke-free workplaces on smoking behaviour: systemic review. BMJ 2002;325:1-7.

2 Mandel LL, Glantz SA. Hedging their bets: tobacco and gambling industries work against smoke-free policies. Tobacco Control 1004;13:268-76.

3 Dearlove JV, Bialous SA, Glantz SA. Tobacco industry manipulation of the hospitality industry to maintain smoking in public places. Tobacco Control 2002;11:94-104.

4 Scollo M, Lal A, Hyland A, et al. Review of the quality of studies on the economic effects of smoke-free policies on the hospitality industry. Tobacco Control 2003; 12:13-20.

5 Glantz SA, Wilson-Loots R. No association of smoke-free ordinances with profits from bingo and charitable games in Massachusetts. Tobacco Contro 2003;12:411-13.

6 Alamar BC, Glantz SA. Smokefree ordinances increase restaurant values. Contemporary Economic Policy 2004;28:520-5.

7 Chase R. Smoking ban may be factor in keeping Delaware casinos competitive. Associated Press State and Local Wire, 2003. http://web.lexisnexis.com/universe/document?_m =aab7a5d5c403ff85dde0930aaf682af3 \&_docnum $=1 \& w c h p=d G L b V \mid z-z S k V b \& \_m d 5$

$=16 a 066912 \mathrm{~d} 56 \mathrm{c} 07 \mathrm{fa} 9147 \mathrm{e} 008 \mathrm{eb} 918 \mathrm{f3}$ (Accessed 30 Aug 2003).

8 Chase R. Dover Downs blames layoffs on Delaware smoking ban. The Associated Press State and Local Wire, 2003. http://web.lexis-nexis.com/ universe/document?_m = aab7a5d5c403ff85dde0930aaf682af3\&_docnum $=21 \& w c h p=d G L b V \mid z-z S k V b \& \_m d 5$

$=557039 \mathrm{c} 54 \mathrm{~d} 22 \mathrm{~b} 08 \mathrm{~d} 1 \mathrm{ed0e} 371 \mathrm{ff} 683871$ (Accessed 30 Aug 2003).

9 New Jersey Senate Health Committee Hearing. New Jersey Legislature, May 19, 2003. http://www.nileg.state.nj.us/media/archive_audio2.asp?KEY $=$ SHH\&SESSION $=2002$ (Accessed 12 Aug 2003).

10 Park Place Entertainment. Park Place Reports Financial Results for First Quarter. 2003. http://investor.parkplace.com/ReleaseDetail.cfm?ReleaselD $=108048 \&$ Category $=$ Earnings\%20Releases (Accessed 22 Aug 2003).

11 The Delaware Lottery. The Delaware Lottery 2002 Annual Report. The Delaware Lottery, 2002. http://delottery.com/pdf/2002annualreport.pdf (Accessed 15 Aug 2003).

12 American Lung Association. Tobacco Policy Trend Alert Clean Indoor Air: The Delaware Campaign Model; 2002 November.

13 The Delaware Lottery. Monthly Proceeds and Distribution. 2004. http:// lottery.state.de.us/videolottery.html (Accessed 5 June 2004).

14 Chained Consumer Price Index. Bureau of Labor Statistics, 2004. http:// www.bls.gov/data/home.htm (Accessed 5 June 2004).

15 Regional Accounts Data Personal Income. Bureau of Economic Analysis, 2003. http://www.bea.gov/bea/regional/ (Accessed 5 June 2004).

16 Simpson J. Lobbyist Sees Expansion for Racinos: Fiscally strapped states not expected to look to Las Vegas-style resort model. Las Vegas Review Journal, 2003. http://reviewjournal.printthis.clickability.com/pt/cpt?action $=$ cpt\&expire $=$ \&url| $=5052771 \& \mathrm{fb}=$

Y\&partnerID = 566 (Accessed 22 Aug 2003)

\section{The Lighter Side}
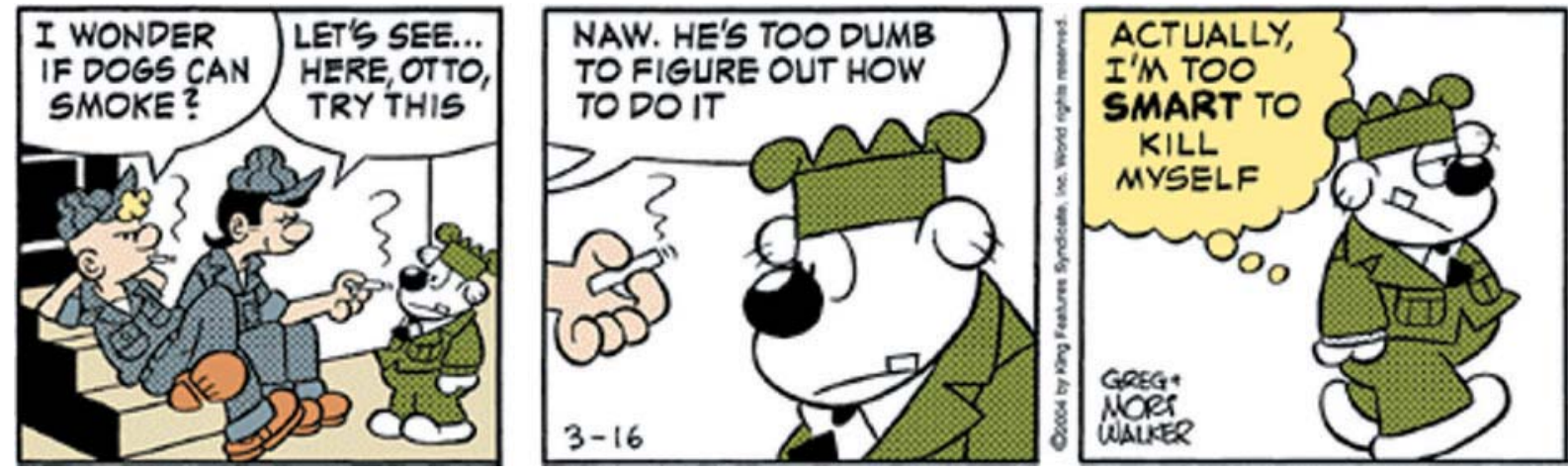

Beetle Bailey, by Greg \& Mort Walker. @ Reprinted with special permission of King Features Syndicate. 


\section{PostScript}

\section{LETTERS}

\section{Biochemical validation of self reported quit rates among Buddhist monks in Cambodia}

Smoking cessation programmes in Cambodia have found that Buddhist monks are highly motivated to quit smoking. Although over $23.4 \%$ of all Buddhist monks smoke, ${ }^{1}$ the self reported quit rates average $87 \%$. The Adventist Development Relief Agency's (ADRA) "Khmer Quit Now" programme has achieved this success through a five day smoking cessation class. ADRA has found that Buddhist monk peer support groups work well; the one year quit rate has been a consistent $87 \%$ over four years in five different Cambodian provinces. This extraordinary quit rate warranted biochemical validation and an explanation of the programme's effective methods.

To investigate the quit rate, 250 monks were identified from Cambodian Wats who had completed the smoking cessation programme. These monks were first interviewed about their smoking status, then administered a saliva test. The monks had no prior knowledge that they would be asked for a saliva sample until after they completed the survey questionnaire. Salivary cotinine, a byproduct of nicotine and marker of smoking status, ${ }^{2}$ was collected using the Orasure oral specimen collection device and analysed using the microplatte enzyme immunoassay technique by the Pasteur Institute in Phnom Penh. A salivary cotinine concentration greater than the cut off ${ }^{3}$ of $10 \mathrm{ng} / \mathrm{ml}$ determined "current smoking" status.

Out of the 250 monks, $224 \quad(89.6 \%)$ reported themselves as non-smokers, whereas only 12 monks (5.3\% false positives) had levels above the cut off. Upon follow up, five of these monks explained that they do smoke, but felt obliged to report themselves as non-smokers during the survey. The remaining seven monks said that they chew tobacco, ${ }^{2}$ denied reporting themselves as nonsmokers, ${ }^{2}$ denied ever smoking, ${ }^{2}$ or were lost for follow up. ${ }^{1}$ This represents a concordance of $94.6 \%$ and a $\kappa$ statistic $^{1}$ specifying that this study is a good $(\kappa=0.598, \mathrm{SE}=0.081$, $\mathrm{p}=0.000$ ) predictor of the monk self report quit rate (table 1 ).

The high level of discipline and motivation among the Smoke Free Buddhist Monk quit programme is not unique to Cambodia. Any
Table 1 Cigarette consumption and ever nicotine replacement therapy (NRT) use of current smokers in 2002*

\begin{tabular}{|c|c|c|c|c|}
\hline & \multirow[b]{2}{*}{$\begin{array}{l}\text { Total } \\
\text { smokers }\end{array}$} & \multicolumn{3}{|c|}{$\begin{array}{l}\text { Smokers according to frequency of smoking } \\
\text { and number of cigs per day }\end{array}$} \\
\hline & & Occasional & $\begin{array}{l}\text { Daily } \\
<15 \text { cigs } / \mathrm{d}\end{array}$ & $\begin{array}{l}\text { Daily } \\
15+\text { cigs/d }\end{array}$ \\
\hline $\begin{array}{l}\text { Ever used NRT ( } n=1914) \\
\text { Reason for using NRT }\end{array}$ & $-31.6(1.5)$ & $-16.3(2.3)$ & $-26.9(3.0)$ & $-47.0(2.2)$ \\
\hline $\begin{array}{l}\text { To quit }(n=1622) \\
\text { To tide over }(n=145) \\
\text { To cut down }(n=75) \\
\text { Just curious }(n=82)\end{array}$ & $\begin{array}{l}86.4(2.1) \\
7.4(1.6) \\
4.0(1.0) \\
4.2(1.0)\end{array}$ & $\begin{array}{l}83.3(5.7) \\
4.6(2.5) \\
4.4(3.5) \\
4.6(2.6)\end{array}$ & $\begin{array}{l}86.5(3.3) \\
5.2(2.1) \\
2.7(1.4) \\
5.5(2.2)\end{array}$ & $\begin{array}{l}87.1(2.7) \\
9.2(2.1) \\
4.6(1.5) \\
3.4(1.1)\end{array}$ \\
\hline
\end{tabular}

smoking cessation programme can achieve similar results with a strong peer support network, frequent motivational monitoring, and a firm quit date. Although many of the Buddhist monks had low cigarette consumption levels before they quit, this study demonstrates the success and simplicity of "natural" quit programmes; the Buddhist monks in this study did not rely on chemical or medicinal methods to stop smoking. They are merely a highly disciplined group of smokers who used available resources to stop smoking.

D Yel, G K Hallen

Tobacco Free Initiative, World Health Organization, Phnom Penh, Cambodia

R G Sinclair, K Mom

Adventist Development and Relief Agency, Cambodia

C T Srey

Pasteur Institute, Phnom Penh, Cambodia

Correspondence to: D Yel; yeld@cam.wpro.who.int doi: $10.1136 /$ tc. 2005.012039

\section{REFERENCES}

1 Adventist Development and Relief Agency, Cambodia. "Smoke Free Cambodian Communities" project. Buddhist monk and Cambodian community prevalence survey, Internal publication, 2004.

2 Benowitz NL. Biomarkers of environmental tobacco smoke exposure. Environ Health Perspect 1999;107(suppl):349-55

3 Vartiainen E, Seppälä T, Lillsunde $P$, et al. Validation of self reported smoking by serum cotinine measurement in a community-based study. J Epidemiol Community Health 2002;56:163-64.
Table 1 Self reported quit rates of Cambodian Buddhist monks

\begin{tabular}{|c|c|c|c|c|c|}
\hline \multirow[b]{2}{*}{ Smoking status } & \multicolumn{2}{|c|}{ Accurate self report } & \multicolumn{2}{|c|}{ False self report } & \multirow{2}{*}{$\frac{\text { Total }}{\text { (n) }}$} \\
\hline & $\overline{\text { (n) }}$ & Concordance $(\%)$ & $\overline{\text { (n) }}$ & $\%$ & \\
\hline Ex-smoker & 22 & $94.64 \%$ & 12 & $5.36 \%$ & 224 \\
\hline Current smoker & 25 & $96.15 \%$ & 1 & $3.85 \%$ & 26 \\
\hline Total & 237 & $94.80 \%$ & 13 & $5.20 \%$ & 250 \\
\hline
\end{tabular}

The Cambodia Adventist Development Relief Agency study on biochemical validation of quit rates, July 2002.

\section{When California smokers use nicotine replacement therapy, most are trying to quit smoking}

Extensive literature exists about nicotine replacement therapy (NRT) efficacy in randomised clinical trials of smoking cessation, yet population data do not show sustained effectiveness after NRT became available over the counter in the USA. ${ }^{2}{ }^{3}$ Some claim that product cost is the main obstacle for its lack of population effectiveness. ${ }^{4}$ A large population based natural experiment is underway in New York that will test this hypothesis. Others suggest that smokers may be using NRT for reasons other than quitting, such as harm reduction or to mitigate withdrawal symptoms when they are unable to smoke. ${ }^{5}$

We present data from the 2002 California Tobacco Survey (CTS) which is part of large population based, random digit dialled surveys conducted triennially to monitor changes in tobacco use and attitudes in California. The methods for this survey are described in detail elsewhere. ${ }^{6}$ In order to assess the purpose and pattern of NRT use among California smokers, the 2002 CTS asked 5498 current smokers the following: Have you ever used a nicotine substitute product such as a patch, gum, inhaler or lozenge? If they answered yes, they were then asked an open ended question: Why did you use it? They could respond with multiple reasons. Interviewers coded responses into four pre-determined categories: to try to quit, to tide me over in situations where I cannot smoke, to replace some cigarettes so I smoke less, and just curious.

In table 1 , we present these results, categorised by smoking level. Ever use of NRT increased with the amount smoked, with almost half $(47 \%)$ of moderate to heavy daily smokers (15+ cigarettes/day), potentially who would benefit the most, having used it in the past. Overall, about one third of smokers tried NRT and most used it to quit $(86.4 \%)$. Less than $10 \%$ used it for any other single reason. Despite the fact that nearly half of current moderate to heavy smokers reported having used NRT in the past, data from the 2002 CTS indicate only $27 \%$ reported using it for their most recent quit attempt that lasted for a day or longer.

These findings suggest that California smokers have tried NRT mainly for cessation, not supporting suggestions that this therapy is 
used mainly to decrease consumption or to overcome craving when smoking is not allowed. However, it is notable that many moderate to heavy cigarette smokers who had previously used NRT did not do so on their most recent attempt. This suggests that some smokers may be questioning the efficacy of NRT for quitting. It is possible that this could be in response to a change in the advertising message promoting NRT, where the current

Table 1 Estimated effects of the smoke-free law

\begin{tabular}{|c|c|c|c|c|c|c|}
\hline \multirow[b]{2}{*}{ Variable } & \multicolumn{3}{|c|}{$\begin{array}{l}\text { Total revenues (weighted least } \\
\text { squares) (\$million) }\end{array}$} & \multicolumn{3}{|c|}{$\begin{array}{l}\text { Average revenue per machine } \\
\text { (ordinary least squares) ( } \$ / \text { machine) }\end{array}$} \\
\hline & Estimate & SE & p Value & Estimate & SE & p Value \\
\hline $\mathrm{P}_{\text {law }}$ (unit/month) & -2.404 & 3.302 & 0.468 & -1158.11 & 745.10 & 0.123 \\
\hline Time (unit/month) & 0.612 & 0.102 & $<0.001$ & 96.47 & 36.70 & 0.010 \\
\hline Time $^{2}$ (unit/month ${ }^{2}$ ) & -0.005 & 0.001 & $<0.001$ & -0.31 & 0.278 & 0.259 \\
\hline Machines (unit/ & 0.003 & 0.001 & & -2.424 & -2.762 & \\
\hline machine) & & & 0.024 & & & $<0.001$ \\
\hline Income (unit/\$million) & 7.568 & 1.087 & $<0.001$ & 10717.00 & 467.00 & $<0.001$ \\
\hline Winter & -4.147 & 0.872 & $<0.001$ & -1353.01 & 314.79 & $<0.001$ \\
\hline$n$ & 101 & & & 101 & & \\
\hline$R^{2}$ & 0.669 & & & 0.639 & & \\
\hline
\end{tabular}
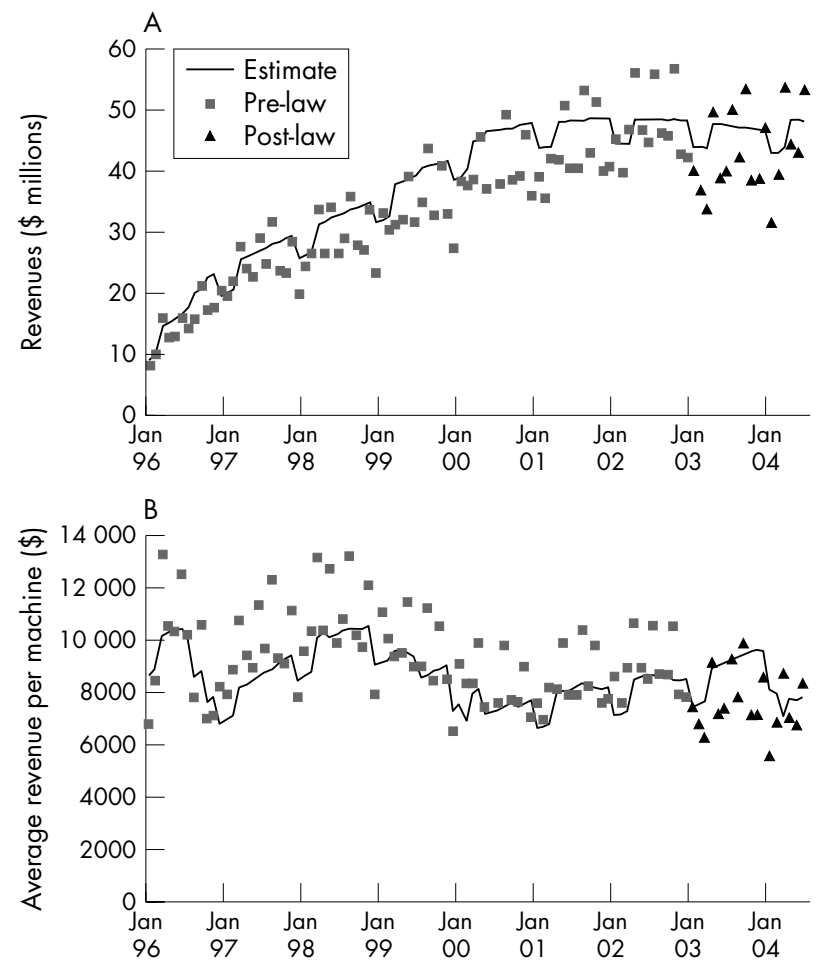

Figure 1 (A) Total revenues increase from the creation of the racinos and then flatten out with the economic downturn. No significant relation between total revenues and the smoke-free law exists. (B) Average revenues per machine vary over time and decrease with the downturn in the economy. No significant relation between average revenues and the smoke-free law exists.
W K Al-Delaimy, E A Gilpin, J P Pierce

Cancer Prevention and Control, University of California, San Diego, Cancer Center, La Jolla, California, USA

Correspondence to: W K Al-Delaimy; waldelaimy@ ucsd.edu

doi: 10.1136/tc.2005.012989

\section{REFERENCES}

1 Silagy C, Lancaster T, Stead L, et al. Nicotine replacement therapy for smoking cessation. Cochrane Database Syst Rev 2004;3:CD000146.

2 Pierce JP, Gilpin EA. Impact of over-the-counter sales on effectiveness of pharmaceutical aids for smoking cessation. JAMA 2002;288:1260-4.

3 Thorndike AN, Biener L, Rigotti NA. Effect on smoking cessation of switching nicotine replacement therapy to over the counter status. Am J Public Health 2002;92:437-42.

4 Cummings KM, Hyland A. Impact of nicotine replacement therapy on smoking behavior. Annu Rev Public Health 2005;26:583-99.

5 Etter JF, Laszlo E, Zellweger JP, et al. Nicotine replacement to reduce cigarette consumption in smokers who are unwilling to quit: a randomized trial. J Clin Psychopharmacol 2002;22:487-95.

6 University of California, San Diego (UCSD) Social Science Data Center. Final reports, technical documentation and data from the California Tobacco Surveys, 2005. http://ssdc.ucsd.edu/ tobacco.

7 Al-Delaimy WK, White MM, Pierce JP. Adolescents' perceptions about quitting and nicotine replacement therapy: findings from the California tobacco survey. Journal of Adolescent Health (in press).

\section{CORRECTION}

doi: 10.1136/tc.2004.008755corr 1

Mandel LL, Alamar BC, Glantz SA. Smokefree law did not affect revenue from gaming in Delaware. Tobacco Control 2005;14:10-12.

This article contains inaccurate results because of a data entry error. Below is an update of table 1 and fig 1 showing the correct results. White's test for heteroskedasticity rejected homoskedasticity $(\mathrm{p}=0.016)$ in the case of total revenues. We corrected for the heteroskedasticity in total revenues by using a weighted least squares analysis using the inverse of the number of video lottery machines as the weight. White's test of the residuals from the weighted regression did not reject homoskedasticity $(\mathrm{p}=0.293)$. Average revenues were homoskedastic $(\mathrm{p}=0.13)$ so we continued to use an unweighted regression. The analysis based on the corrected data confirms the results of the published paper, that the smoke-free law had no affect on revenue from gaming in Delaware. 